\title{
Occurrence of antibodies anti -Toxoplasma gondii, Neospora caninum and Leptospira interrogans in a captive deer herd in Southern Brazil
}

\section{Ocorrência de anticorpos anti - Toxoplasma gondii, Neospora caninum e Leptospira interrogans} em um rebanho de cervídeos de cativeiro do sul do Brasil

Cristina Kraemer Zimpel ${ }^{1 \mathrm{a}}$; Ana Laura Grazziotin ${ }^{2 a}$; Ivan Roque de Barros Filho ${ }^{3}$; Ana Marcia de Sa Guimaraes ${ }^{1}$; Leonilda Correia dos Santos ${ }^{3}$; Wanderlei de Moraes ${ }^{3,4}$; Zalmir Silvino Cubas ${ }^{4}$; Marcos Jose de Oliveira ${ }^{4}$; Edviges Maristela Pituco ${ }^{5}$; Maria do Carmo Custódio de Souza Hunold Lara ${ }^{5}$; Eliana Monteforte Cassaro Villalobos ${ }^{5}$; Lília Marcia Paulin Silva ; Elenice Maria Sequetin Cunha ${ }^{5}$; Vanessa Castro ${ }^{5}$; Alexander Welker Biondo ${ }^{3 *}$

${ }^{1}$ Faculdade de Medicina Veterinária e Zootecnia, Universidade de São Paulo - USP, São Paulo, SP, Brasil

${ }^{2}$ Centro de Biociências e Biotecnologia, Universidade Estadual do Norte Fluminense Darcy Ribeiro - UENF, Campos dos Goytacazes, RJ, Brasil

${ }^{3}$ Departamento de Medicina Veterinária, Universidade Federal do Paraná - UFPR, Curitiba, PR, Brasil

${ }^{4}$ Refúgio Biológico Bela Vista, Usina Hidrelétrica de Itaipu Binacional, Foz do Iguaçu, PR, Brasil

${ }^{5}$ Centro de Pesquisa e Desenvolvimento de Sanidade Animal, Instituto Biológico de São Paulo, São Paulo, SP, Brasil

Received February 27, 2015

Accepted June 24, 2015

\begin{abstract}
A large number of Brazilian zoos keep many endangered species of deer, however, very few disease surveillance studies have been conducted among captive cervids. Blood samples from 32 Brazilian deer (Blastocerus dichotomus, Mazama nana and Mazama americana) kept in captivity at Bela Vista Biological Sanctuary (Foz do Iguaçu, Brazil) were investigated for 10 ruminant pathogens, with the aims of monitoring deer health status and evaluating any potential zoonotic risk. Deer serum samples were tested for Brucella abortus, Leptospira (23 serovars), Toxoplasma gondii, Neospora caninum, bovine viral diarrhea virus, infectious bovine rhinotracheitis virus, foot-and-mouth disease virus, western equine encephalitis virus, eastern equine encephalitis virus and Venezuelan equine encephalitis virus. Antibodies against T. gondii (15.6\%), $N$. caninum $(6.2 \%)$ and $L$. interrogans serogroup Serjoe (3.1\%) were detected. The serological results for all other infectious agents were negative. The deer were considered to be clinically healthy and asymptomatic regarding any disease. Compared with studies on free-ranging deer, the prevalences of the same agents tested among the captive deer kept at the Sanctuary were lower, thus indicating good sanitary conditions and high-quality management practices at the zoo.
\end{abstract}

Keywords: Deer, Leptospira, Neospora caninum, serosurvey, Toxoplasma gondii, zoo.

\section{Resumo}

Um grande número de zoológicos brasileiros abriga espécies de cervídeos ameaçados de extinção, entretanto, estudos de vigilância de doenças em cervídeos de cativeiro são escassos. Amostras de sangue de 32 cervídeos brasileiros (Blastocerus dichotomus, Mazama nana e Mazama americana), mantidos em cativeiro no Refúgio Biológico Bela Vista (Foz do Iguaçu, Brasil), foram investigados para 10 patógenos de ruminantes, visando monitorar o estado de saúde dos cervídeos e avaliar a presença de agentes zoonóticos. As amostras de soro foram testadas para Brucella abortus, Leptospira (23 sorovares), Toxoplasma gondii, Neospora caninum, diarreia viral bovina, rinotraqueíte infecciosa bovina, febre aftosa, encefalomielite equina do oeste, encefalomielite equina do leste e encefalomielite equina venezuelana. Foram detectados anticorpos para T. gondii (15,6\%), N. caninum (6,2\%) e para L. interrogans sorogrupo Serjoe (3,1\%). As sorologias apresentaram resultado negativo para as demais doenças. Os cervídeos foram considerados clinicamente sadios e assintomáticos para doenças. Comparados aos estudos de populaçóes de vida livre, as soroprevalências para os mesmos agentes testados foram menores para os cervídeos mantidos no Refúgio, indicando as boas condiçôes sanitárias e a qualidade das práticas de manejo no zoológico.

Palavras-chave: Cervídeo, Leptospira, Neospora caninum, sorologia, Toxoplasma gondii, zoológico.

${ }^{*}$ Corresponding author: Alexander Welker Biondo. Departamento de 
Disease surveillance has an essential role in the management of wild animals in captivity. Zoo animals are susceptible to a wide range of infectious agents, due to their closer contact with humans and other captive animals, as well as their confinement in herds, depending on the species (MURAKAMI et al., 2012). Moreover, living conditions in captivity differ greatly from the conditions of animals living in the wild. Captive animals may be more exposed to stress and behavioral changes, which might lead to fragile health status (PEARSON et al., 2015). A large number of Brazilian zoos are responsible for captive deer conservation and breeding programs, however, disease surveillance studies among captive deer are scarce because of handling difficulties and high mortality.

Serological and molecular studies among free-ranging Brazilian deer have suggested that deer are exposed to a wide spectrum of parasitic, bacterial and viral pathogens, such as Toxoplasma gondii (FERREIRA et al., 1997), Neospora caninum (TIEMANN et al., 2005a), Babesia spp. and Theileria spp. (SILVEIRA et al., 2011), Ehrlichia chaffeensis and Anaplasma spp. (MACHADO et al., 2006; SACCHI et al., 2012), Mycoplasma ovis (GRAZZIOTIN et al., 2011a), Leptospira spp. (VIEIRA et al., 2011) and foot-and-mouth disease virus (ARAUJO et al., 2010). To date, only two studies related to neosporosis and mycoplasmosis investigations have been conducted among captive deer in Brazil (TIEMANN et al., 2005b; GRAZZIOTIN et al., 2011b). In the present work, we investigated the serological profile of a ruminant pathogen panel in a population of deer (Blastocerus dichotomus, Mazama nana and Mazama americana) kept in captivity at Bela Vista Biological Sanctuary (BVBS), with the aims of monitoring deer health status and evaluating any potential zoonotic risk. Considering that BVBS maintains one of the largest captive herd of Mazama spp. in Brazil and that little is known about their health status, this population study may provide relevant information on deer management, diseases surveillance and zoonotic risk for other conservation units.

BVBS ( $25^{\circ} 26^{\prime} 57^{\prime \prime} \mathrm{S}$ and $\left.54^{\circ} 33^{\prime} 18^{\prime \prime} \mathrm{W}\right)$ is an environmental conservation unit in the Parana river basin, located in the area of the Itaipu Binacional hydroelectric power plant (Foz do Iguaçu, Brazil) (Figure 1). The sanctuary is committed to protection, maintenance, rehabilitation and reintroduction of threatened wild animals, along with breeding programs for these species. The region is considered to be a World Heritage Site (UNESCO/WHC, 2015) and is home to a diversity of endangered species, including deer. The marsh deer ( $B$. dichotomus) has been listed as a vulnerable species since 1982 because of past and current habitat losses (DUARTE et al., 2008a), while insufficient information is available for the Brazilian dwarf brocket deer (M. nana) and red brocket deer (M. americana) (APRIL \& DUARTE, 2008; DUARTE et al., 2008b). Similarly, little is known regarding deer exposure to infectious agents, or regarding the role that captive deer might play as reservoirs for such agents.

Serum samples were collected from 32 animals (22 M. nana, six $B$. dichotomus and four $M$. americana) kept at BVBS. All the deer are kept in areas demarcated by metal fences, in small groups of the same species. A group of six marsh deer and another group of three dwarf brocket deer are located in the zoo area for exhibition in distinct enclosures apart from one another, while the other 23 deer
(20 Brazilian dwarf brocket and three red brocket deer) are kept alone or in small groups (3-5 animals) in the breeding area, away from the zoo touristic route. Animals were chemically immobilized using a blowgun whose darts contained an association of $10 \%$ ketamine hydrochloride $(7 \mathrm{mg} / \mathrm{kg}$ ) and $2 \%$ xylazine hydrochloride $(0.5 \mathrm{mg} / \mathrm{kg}$ ) for M. nana and M. americana, whereas $20 \%$ zolazepam $(3 \mathrm{mg} / \mathrm{kg})$ and $2 \%$ xylazine hydrochloride $(0.5 \mathrm{mg} / \mathrm{kg})$ were administered for $B$. dichotomus. Blood samples were collected by means of jugular venipuncture using vacuum tubes without anticoagulant. The samples were clotted and centrifuged, and the serum samples were stored at $-20{ }^{\circ} \mathrm{C}$ until assayed. This study was approved by the federal regulatory agency IBAMA (Brazilian Institute for the Environment and Renewable Resources) under the protocol number 22.158-2 (November 12, 2009) and was conducted in accordance with IBAMA's ethical rules.

All serological tests were conducted at the Biological Institute of Sáo Paulo, Brazil, according to the established and internationally recommended protocols of the World Organization for Animal Health regulations (OIE, 2008). Serum samples were tested for antibody activity against 10 infectious agents. Serum neutralization assays were used to detect antibody activity against bovine viral diarrhea virus (BVD) (NADL strain) (EDWARDS, 1990), infectious bovine rhinotracheitis virus (IBR) (herpesvirus type 1, Los Angeles strain) (BITSCH, 1978), western equine encephalitis virus (WEE) (Tatuí strain), eastern equine encephalitis virus (EEE) (TR25717 strain) and Venezuelan equine encephalitis virus (VEE) (OIE, 2008). Cutoff titers of 1:10 for BVD, 2 (1:4) for IBR and 10 for EEE, WEE and VEE were used. Agar gel immunodiffusion was performed for foot-and-mouth disease virus (FMD): samples were considered positive when a line appeared between two consecutive wells (MCVICAR \& SUTMOLLER, 1970). Presence of antibodies against 23 Leptospira serovars (see Table 1 for details) was tested by means of the microscopic agglutination test (MAT) (OIE, 2008) and against Brucella abortus 1119-3 strain by means of the complement fixation test (CFT) (OIE, 2008) and rose Bengal test (RBT) (MORGAN et al., 1969). Serum samples giving titers greater than or equal to 1:100 were considered positive for

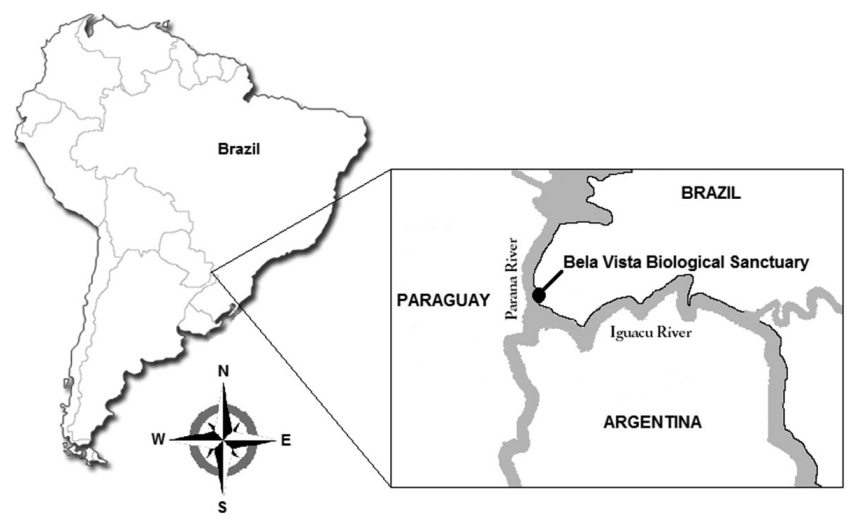

Figure 1. Sampling location for captive deer in Brazil. Bela Vista

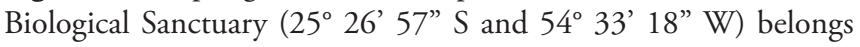
to the world's largest hydroelectric power plant (Itaipu Binacional) and is located in a large environmental conservation area shared by Paraguay, Argentina and Brazil. 
Table 1. Prevalence of ten infectious disease agents in the Brazilian deer population.

\begin{tabular}{|c|c|c|c|c|}
\hline Pathogen tested ${ }^{a}$ & Method $^{\mathrm{c}}$ & B. dichotomus & M. nana & M. americana \\
\hline BVD virus & $\mathrm{SN}$ & $0 / 6$ & $0 / 22$ & $0 / 4$ \\
\hline IBR virus & SN & $0 / 6$ & $0 / 22$ & $0 / 4$ \\
\hline FMD virus & AGID & $0 / 6$ & $0 / 22$ & $0 / 4$ \\
\hline Leptospira spp. ${ }^{\mathrm{b}}$ & MAT & $1 / 6$ & $0 / 22$ & $0 / 4$ \\
\hline Brucella abortus & RBT, CT & $0 / 6$ & $0 / 22$ & $0 / 4$ \\
\hline Neospora caninum & ELISA & $1 / 6$ & $1 / 22$ & $0 / 4$ \\
\hline Toxoplasma gondii & IFAT & $2 / 6$ & $2 / 22$ & $1 / 4$ \\
\hline EEE virus & SN & $0 / 6$ & $0 / 22$ & $0 / 4$ \\
\hline WEE virus & $\mathrm{SN}$ & $0 / 6$ & $0 / 22$ & $0 / 4$ \\
\hline VEE virus & SN & $0 / 6$ & $0 / 22$ & $0 / 4$ \\
\hline
\end{tabular}

${ }^{2} \mathrm{BVD}$, Bovine viral diarrhea; IBR, Infectious bovine rhinotracheitis; FMD, Foot and mouth disease; EEE, Eastern encephalitis equine; WEE, Western encephalitis equine; VEE, Venezuelan encephalitis equine. ${ }^{b}$ List of Leptospira spp. tested in this study according to their serogroup and sorovar (within parenthesis) designation: a) Leptospira borgpetersenii serogroup Ballum (serovar castellonis), Javanica (javanica), Mini (mini), Tarassovi (tarassovi), and Celledoni (whitcombi); b) Leptospira interrogans serogroup Australis (serovar australis and bratislava), Autumnalis (autumnalis), Bataviae (bataviae), Canicola (canicola), Icterohaemorrhagiae (icterohaemorrhagiae and copenhageni), Hebdomadis (hebdomadis), Pomona (pomona), Pyrogenes (pyrogenes), Sentot (sentot), and Serjoe (hardjo and wolff). c) Leptospira kirshneri serogroup Autumnalis (butembo), Cynopteri (cynopteri), Grippotyphosa (grippotyphosa), Panama (panama), and Shermani (shermani). cSN, serum neutralization; AGID, agar gel immunodiffusion; MAT, microscopic agglutination test; RBT, rose Bengal test; CT, complement fixation; ELISA, enzyme-linked immunodiffusion assay; IFAT, indirect fluorescent antibody test.

Leptospira spp., whereas 20 international complement fixation test units per $\mathrm{mL}$ and any visible reaction were considered positive in the CFT and RBT, respectively. An ELISA test for antibodies against $N$. caninum (HerdChek Neospora caninum Antibody Test Kit, IDEXX Laboratories Inc., Maine, USA) was used according to manufacturer's instructions. As a confirmatory assay, positive samples were then tested by means of a $N$. caninum strain NC-1 indirect fluorescent antibody test (IFAT) (CONRAD et al., 1993) using anti-bovine IgG (cutoff titer of 1:25). The serological analysis on $T$. gondii was performed by means of IFAT using anti-bovine IgG antibodies (cutoff titer of 1:64) as recommended by manufacturer (Imunoteste ${ }^{\circledR}$ Toxoplasma gondii, IMUNODOT Diagnósticos Ltda., Jaboticabal, Brazil). Positive and negative controls of bovine origin were used for all tests.

All the deer were in good body condition with no evidence of diseases at the time of physical examination and blood sampling. Remarkably, all the animals recovered well from the anesthesia procedure and no mortality was registered. Regarding the serological panel tests, $15.6 \%(5 / 32), 6.2 \%(2 / 32)$ and $3.1 \%$ (1/32) of the animals were positive for T. gondii, N. caninum and the $L$. interrogans serogroup Serjoe, respectively. All the serum samples were negative for antibody activity against $B$. abortus, BVD, IBR, FMD, EEE, WEE and VEE (Table 1).

A wide range of animals may be infected by the apicomplexan protozoa $N$. caninum and $T$. gondii. The definitive hosts for $N$. caninum are dogs and wild canids (DUBEY et al., 2011; MUNHOZ et al., 2013) while for $T$. gondii, cats and wild felids (ARAMINI et al., 1998; DUBEY \& PROWELL, 2013) are the definitive hosts. Oocysts shed in the environment by the definitive hosts may be ingested by susceptible animals such as wild ruminants causing abortion in sheep, goats and cattle (MORENO et al., 2012; HOAR et al., 1996). Although there is no evidence of abortion in deer, several serological studies have indicated that these wild ruminants might be reservoirs for both protozoa (DUBEY et al., 2009). Among 32 captive deer at BVBS, $15.6 \%$ and $6.2 \%$ were positive for $T$. gondii and $N$. caninum, respectively. These prevalences were lower than in other serological surveys conducted in Brazil. In relation to T. gondii, 27.2\% (18/66) of the free-ranging marsh deer in the Pantanal region (marshland at $19^{\circ} 50^{\prime} \mathrm{S}$ and $\left.56^{\circ} 33^{\prime} \mathrm{W}\right)$ and $12.2 \%(5 / 41)$ of the pampas deer (Ozotoceros bezoarticus) in a national park (dry region at $18^{\circ}$ $15^{\prime} \mathrm{S}$ and $52^{\circ} 53^{\prime} \mathrm{W}$ ) were seropositive (FERREIRA et al., 1997). Among 150 Mazama spp. in captive herds and zoos located in different regions of Brazil, $42 \%$ were positive for $N$. caninum (TIEMANN et al., 2005b) while among free-ranging pampas deer, $13 \%(3 / 23)$ of the animals in a national park and $75 \%$ $(12 / 16)$ of the animals in the Pantanal region were positive (TIEMANN et al., 2005a). The prevalences found at BVBS may be related to the proximity between the deer's zoo areas and the other wild mammals' zoo areas, including canids and felids, which if infected by $N$. caninum and $T$. gondii, might be the source of infection for zoo herbivores. Previous serological studies showed that $66.6 \%(38 / 57)$ of the felids at BVBS were exposed to T. gondii (ULLMANN et al., 2010). In addition, the housekeeping staff observed sporadic presence of feral cats in the zoo area, which could be playing a role in the oocysts dissemination. Nonetheless, we cannot rule out the possibility of congenital transmission, which has already been demonstrated in relation to $N$. caninum among white-tailed deer (DUBEY et al., 2013).

Leptospirosis has been a management concern in zoos in which there is greater animal density than would be expected in nature (LELU et al., 2015). Infected deer may show subclinical or clinical disease evolving to death (FAIRLEY et al., 1984; TONIN et al., 2011). Moreover, these animals have been also indicated as reservoir for Leptospira spp. (JORI et al., 2014). A serological comparison between two distinct pampas deer populations showed that there was no exposure to Leptospira spp. in the population from a dry region (Emas National Park, Goiás, Brazil) while 9.7\% (4/41) (GIRIO et al., 2004) and 24\% (4/17) (MATHIAS et al., 1999) of the animals from the wetland region (Pantanal, Mato Grosso do Sul, Brazil) were seropositive for the serogroups Serjoe and Mini. In contrast, none of the ten $M$. americana investigated were positive 
in Pantanal (GIRIO et al., 2004). At BVBS, only one animal (3.1\%) was positive for the serogroup Serjoe. A previous serosurvey for Leptospira spp. conducted among felids at BVBS showed that 3.5\% (2/57) of the animals were positive for the serogroups Cynoptery and Autumnalis (ULLMANN et al., 2012). Although these findings showed distinct serogroup patterns between felids and deer, it is not known whether the felids are transmitting the agent to the deer via shedding into the environment. Regarding the low prevalence and lack of clinical signs of disease in the deer herd and also in the felids, leptospirosis does not seem to pose an animal management concern at BVBS. However, since maintenance of Leptospira spp. in the environment is related to humid weather conditions but the blood collections were made during the dry season, seropositivity rate may vary over time. Since leptospirosis may affect humans and is easily transmitted, serological indications should be taken into consideration in zoonosis prevention programs in zoos.

Regarding BVBS management practices and building areas, deer maintained for zoo exhibition are separated from those placed in the breeding area. These areas are distant from one another, preventing direct and indirect contact among groups kept in distinct locations. At the zoo area, 4/9 (44.4\%) of deer were T. gondii, N. caninum and $L$. interrogans serogroup Serjoe seropositive, while only 3/23 (13\%) of deer showed anti-Toxoplasma and anti-Neospora antibodies at the breeding area. Regarding to animal origin, 25/32 (78\%) of the animals were born in captivity comprising 6/25 (24\%) of the seropositive animals whereas only $1 / 7$ (14\%) of those free-living born animals was seropositive and this individual was located in the zoo area. The distinct seroprevalence between groups could be possibly related to the occasional presence of feral cats in the zoo area that might be reservoirs of $T$. gondii for the zoo animals and to the proximity between the enclosures of the crab-eating fox (Cerdocyon thous), jaguar (Panthera onca) and ocelot (Leopardus pardalis) to the deer's enclosures. In contrast, the 23 deer distributed in 13 enclosures separated by fences at the breeding area have no proximity with other species. The overall low seroprevalence of deer for the tested agents at BVBS compared to other previous studies is possibly related to several effective management practices, including the distance between zoo and breeding areas, limited animal transfers between both areas, distinct housekeeping staff teams for zoo and for breeding areas, stringent animal isolation during quarantine for all new arrivals from other institutions or from wildlife, periodic fecal and hematological examinations as well treatments for parasites, periodic pest control, hygiene and health care procedures while handling different species during the workday, the cleanness of enclosures and the periodic housekeeping staff supervision.

Zoos, conservation units and breeding stations are responsible for genetic conservation of wild animals, especially with regard to endangered species. Management strategies for captive animals in such settings are essential for preventing diseases and animal losses. In our serological surveillance, we found that captive deer have been exposed to $T$. gondii, $N$. caninum and L. interrogans serogroup Serjoe at some point during their lives. Previous studies showed that felids from the same zoo areas were also exposed to T. gondii and Leptospira spp. (ULLMANN et al., 2010; ULLMANN et al., 2012). In these studies and ours, tested felids and deer were asymptomatic indicating that these animals could be playing roles as reservoirs of the mentioned pathogens. Within our studied deer population, those animals located in the breeding areas showed lower positivity compared to the ones located in the zoo areas. It was possibly due to the greater distance between deer and other animals in the breeding area compared to the zoo area and no presence of feral cats, decreasing the risk of inter-species transmission. Moreover, the seroprevalence rates found for deer at BVBS were lower than those previously reported in other deer populations and may reflect the good sanitary conditions and high-quality zoo practices. Finally, more disease surveillance studies in other captive deer populations will be important for comparative analysis and to establish the most suitable deer management protocol.

\section{Acknowledgements}

The authors would like to thank the personal at Bela Vista Biological Sanctuary for all the help kindly given during sample collection from the studied animals.

\section{References}

April VV, Duarte JMB. Mazama nana. The IUCN Red List of Threatened Species. Version 2014.2 [online]. 2008 [cited 2014 Nov 7]. Available from: http://www.iucnredlist.org/

Aramini JJ, Stephen C, Dubey JP. Toxoplasma gondii in Vancouver Island cougars (Felis concolor vancouverensis): serology and oocyst shedding. $J$ Parasitol 1998; 84(2): 438-440. http://dx.doi.org/10.2307/3284508. PMid:9576522.

Araújo JP Jr, Nogueira MF, Duarte JM. Survey for foot-and-mouth disease in the endangered marsh deer (Blastocerus dichotomus) from marshlands of the Parana River Basin, Brazil. JWildl Dis 2010; 46(3): 939-943. http:// dx.doi.org/10.7589/0090-3558-46.3.939. PMid:20688701.

Bitsch V. The P 37/24 modification of the infectious bovine rhinotracheitis virus-serum neutralization test. Acta Vet Scand 1978; 19(4): 497-505. PMid:217258.

Conrad PA, Sverlow K, Anderson M, Rowe J, BonDurant R, Tuter $\mathrm{G}$, et al. Detection of serum antibody responses in cattle with natural or experimental Neospora infections. J Vet Diagn Invest 1993; 5(4): $572-$ 578. http://dx.doi.org/10.1177/104063879300500412. PMid:8286457.

Duarte JMB, Varela D, Piozavan U, Beccaceci MD, Garcia JE. Blastocerus dichotomus. The IUCN Red List of Threatened Species. Version 2014.2 [online]. 2008a [cited 2014 Nov 7]. Available from: http://www.iucnredlist.org/

Duarte JMB, Vogliotti A, Barbanti M. Mazama americana. The IUCN Red List of Threatened Species. Version 2014.2 [online]. 2008b [cited 2014 Nov 7]. Available from: http://www.iucnredlist.org/

Dubey JP, Jenkins MC, Kwok OC, Zink RL, Michalski ML, Ulrich V, et al. Seroprevalence of Neospora caninum and Toxoplasma gondii antibodies in white-tailed deer (Odocoileus virginianus) from Iowa and Minnesota using four serologic tests. Vet Parasitol 2009; 161(3-4): 330-334. http:// dx.doi.org/10.1016/j.vetpar.2009.01.002. PMid:19285809.

Dubey JP, Jenkins MC, Rajendran C, Miska K, Ferreira LR, Martins J, et al. Gray wolf (Canis lupus) is a natural definitive host for Neospora caninum. 
Vet Parasitol 2011; 181(2-4): 382-387. http://dx.doi.org/10.1016/j. vetpar.2011.05.018. PMid:21640485.

Dubey JP, Jenkins MC, Kwok OC, Ferreira LR, Choudhary S, Verma SK, et al. Congenital transmission of Neospora caninum in white-tailed deer (Odocoileus virginianus). Vet Parasitol 2013; 196(3-4): 519-522. http://dx.doi.org/10.1016/j.vetpar.2013.03.004. PMid:23566408.

Dubey JP, Prowell M. Ante-mortem diagnosis, diarrhea, oocyst shedding, treatment, isolation, and genetic typing of Toxoplasma gondii associated with clinical toxoplasmosis in a naturally infected cat. J Parasitol 2013; 99(1): 158-160. http://dx.doi.org/10.1645/GE-3257.1. PMid:22924914.

Edwards S. The diagnosis of bovine virus diarrhoea-mucosal disease in cattle. Rev Sci Tech 1990; 9(1): 115-130. PMid:1966717.

Fairley RA, Scholium LM, Blackmoret DK. Leptospirosis associated with serovars hardjo and pomona in red deer calves (Cervus elaphus). $N$ Z Vet J 1984; 32(5): 76-78. http://dx.doi.org/10.1080/00480169.1984 .35069. PMid:16031052.

Ferreira RA, Mineo JR, Duarte JM, Silva DA, Patarroyo JH. Toxoplasmosis in naturally infected deer from Brazil. JWildl Dis 1997; 33(4): 896-899. http://dx.doi.org/10.7589/0090-3558-33.4.896. PMid:9391980.

Girio RJS, Pereira FLG, Marchiori-Filho M, Mathias LA, Herreira RCP, Alessi AC, et al. Pesquisa de anticorpos contra Leptospira spp. em animais silvestres e em estado feral da região de Nhecolândia, Mato Grosso do Sul, Brasil. Utilização da técnica de imuno-histoquímica para detecção do agente. Cienc Rural 2004; 34(1): 165-169. http://dx.doi.org/10.1590/ S0103-84782004000100025.

Grazziotin AL, Duarte JM, Szabó MP, Santos AP, Guimarães AM, Mohamed A, et al. Prevalence and molecular characterization of Mycoplasma ovis in selected free-ranging Brazilian deer populations. J Wildl Dis 2011a; 47(4): 1005-1011. http://dx.doi.org/10.7589/0090-3558-47.4.1005. PMid:22102675.

Grazziotin AL, Santos AP, Guimarães AM, Mohamed A, Cubas ZS, de Oliveira MJ, et al. Mycoplasma ovis in captive cervids: prevalence, molecular characterization and phylogeny. Vet Microbiol2011b; 152(3-4): 415-419. http://dx.doi.org/10.1016/j.vetmic.2011.05.001. PMid:21640523.

Hoar BR, Ribble CS, Spitzer CC, Spitzer PG, Janzen ED. Investigation of pregnancy losses in beef cattle herds associated with Neospora sp. infection. Can Vet J 1996; 37(6): 364-366. PMid:8689597.

Jori F, Godfroid J, Michel AL, Potts AD, Jaumally MR, Sauzier J, et al. An assessment of zoonotic and production limiting pathogens in rusa deer (Cervus timorensis rusa) from Mauritius. Transbound Emerg Dis 2014;61(S1 Suppl 1): 31-42. http://dx.doi.org/10.1111/tbed.12206. PMid:24382104.

Lelu M, Muñoz-Zanzi C, Higgins B, Galloway R. Seroepidemiology of leptospirosis in dogs from rural and slum communities of Los Rios Region, Chile. BMC Vet Res 2015; 11(31): 1-8. http://dx.doi.org/10.1186/ s12917-015-0341-9. PMid:25880871.

Machado RZ, Duarte JM, Dagnone AS, Szabó MP. Detection of Ehrlichia chaffeensis in Brazilian marsh deer (Blastocerus dichotomus). Vet Parasitol 2006; 139(1-3): 262-266. http://dx.doi.org/10.1016/j.vetpar.2006.02.038. PMid:16621285.

Mathias LA, Girio RJ, Duarte JM. Serosurvey for antibodies against Brucella abortus and Leptospira interrogans in pampas deer from Brazil. J Wildl Dis 1999; 35(1): 112-114. http://dx.doi.org/10.7589/0090-355835.1.112. PMid:10073359.
McVicar JW, Sutmoller P. Foot-and-mouth disease: the agar gel diffusion precipitin test for antibody to virus-infection-associated (via) antigen as a tool for epizootiologic surveys. Am J Epidemiol 1970; 92(4): 273-278. PMid:4989807.

Moreno B, Collantes-Fernández E, Villa A, Navarro A, Regidor-Cerrillo J, Ortega-Mora LM. Occurrence of Neospora caninum and Toxoplasma gondii infections in ovine and caprine abortions. Vet Parasitol 2012; 187(1-2): 312-318. http://dx.doi.org/10.1016/j.vetpar.2011.12.034. PMid:22260901.

Morgan WJB, MacKinnon DJ, Lawson JR, Cullen GA. The rose bengal plate agglutination test in the diagnosis of brucellosis. Vet Rec 1969; 85(23): 636-641. PMid:5358072.

Munhoz AD, Mineo TW, Alessi AC, Lopes CW, Machado RZ. Assessment of experimental infection for dogs using Gallus gallus chorioallantoic membranes inoculated with Neospora caninum. Rev Bras Parasitol Vet 2013 22(4): 565-570. http://dx.doi.org/10.1590/S1984-29612013000400018. PMid:24473883.

Murakami PS, Monego F, Ho JL, Gibson A, Vilani RGDOC, Soresini GCG, et al. An outbreak of tuberculosis by Mycobacterium bovis in coatis (Nasua nasua). J Zoo Wildl Med 2012; 43(2): 338-341. http://dx.doi. org/10.1638/2010-0043.1. PMid:22779238.

Pearson BL, Reeder DM, Judge PG. Crowding increases salivary cortisol but not self-directed behavior in captive baboons. Am J Primatol 2015 77(4): 462-467. http://dx.doi.org/10.1002/ajp.22363. PMid:25598488.

Sacchi AB, Duarte JM, André MR, Machado RZ. Prevalence and molecular characterization of Anaplasmataceae agents in free-ranging Brazilian marsh deer (Blastocerus dichotomus). Comp Immunol Microbiol Infect Dis 2012; 35(4): 325-334. http://dx.doi.org/10.1016/j.cimid.2012.02.001. PMid:22381686.

Silveira JA, Rabelo EM, Ribeiro MF. Detection of Theileria and Babesia in brown brocket deer (Mazama gouazoubira) and marsh deer (Blastocerus dichotomus) in the State of Minas Gerais, Brazil. Vet Parasitol 2011; 177(1-2): 61-66. http://dx.doi.org/10.1016/j.vetpar.2010.10.044 PMid:21354704.

Tiemann JC, Souza SL, Rodrigues AA, Duarte JM, Gennari SM. Environmental effect on the occurrence of anti-Neospora caninum antibodies in pampas-deer (Ozotoceros bezoarticus). Vet Parasitol 2005a; 134(1-2) 73-76. http://dx.doi.org/10.1016/j.vetpar.2005.07.015. PMid:16112811.

Tiemann JC, Rodrigues AA, Souza SL, Duarte JM, Gennari SM. Occurrence of anti-Neospora caninum antibodies in Brazilian cervids kept in captivity. Vet Parasitol 2005b; 129(3-4): 341-343. http://dx.doi. org/10.1016/j.vetpar.2004.12.016. PMid:15845290.

Tonin AA, Azevedo MI, Silva AS, Santos LG, Moura J Jr, Martins JLR, et al. Infection in the pampas deer (Ozotoceros bezoarticus) by four serotypes of Leptospira interrogans. Comp Clin Pathol 2011; 20(3): 267268. http://dx.doi.org/10.1007/s00580-010-1100-8.

Ullmann LS, da Silva RC, de Moraes W, Cubas ZS, dos Santos LC, Hoffmann JL, et al. Serological survey of Toxoplasma gondii in captive Neotropical felids from Southern Brazil. Vet Parasitol 2010; 172(1-2): 144 146. http://dx.doi.org/10.1016/j.vetpar.2010.04.013. PMid:20472340.

Ullmann LS, Hoffmann JL, Moraes W, Cubas ZS, Santos LC, Silva $\mathrm{RC}$, et al. Serologic survey for Leptospira spp. in captive neotropical felids in Foz do Iguaçu, Paraná, Brazil. J Zoo Wildl Med 2012; 43(2): 223-228. http://dx.doi.org/10.1638/2010-0091.1. PMid:22779223. 
United Nations Educational, Scientific and Cultural Organization. World Heritage Centre - UNESCO/WHC. Iguazu National Park [online]. [cited 2015 Mar 02]. Available from: http://whc.unesco.org/en/list/303

Vieira AS, Rosinha GM, Oliveira CE, Vasconcellos SA, Lima-Borges PA, Tomás WM, et al. Survey of Leptospira spp. in pampas deer (Ozotoceros bezoarticus) in the Pantanal wetlands of the state of Mato Grosso do Sul, Brazil by serology and polymerase chain reaction. Mem
Inst Oswaldo Cruz 2011; 106(6): 763-768. http://dx.doi.org/10.1590/ S0074-02762011000600019. PMid:22012234.

World Organisation for Animal Health - OIE. Manual of diagnostic tests and vaccines for terrestrial animals (mammals, birds and bees) [online]. 2008 [cited 2015 Mar 02]. Available from: http://web.oie.int/eng/normes/ MMANUAL/A_Index.htm 